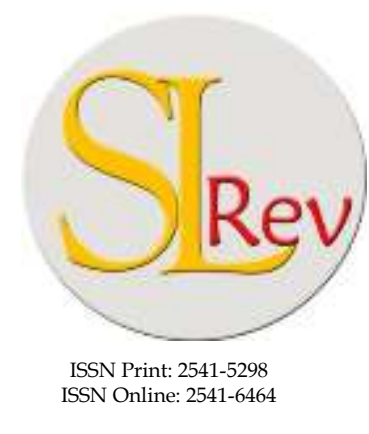

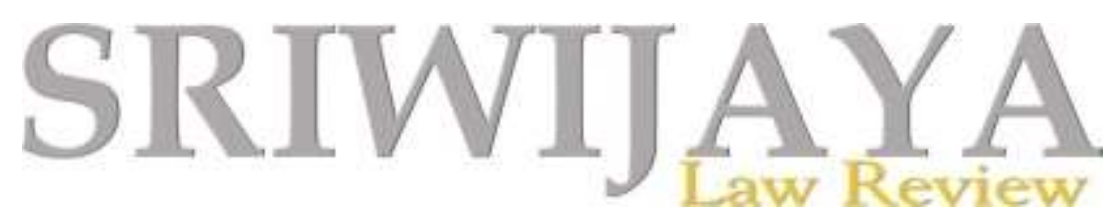

Editorial Office: Faculty of Law, Sriwijaya University, Jalan Srijaya Negara, Palembang, South Sumatra 30139, Indonesia. Phone: +62711-580063Fax: +62711-581179

E-mail: sriwijayalawreview@unsri.ac.id| sriwijayalawreview@gmail.com Website: http://journal.fh.unsri.ac.id/index.php/sriwijayalawreview

\title{
Legal Reasons Underlying Demonopolization by State-Owned Enterprises in Indonesia
}

\author{
Putu Samawati*
}

\begin{abstract}
Demonopolization policy towards PT. PLN (Persero) and PT. Pelindo (Persero) conducted by the Indonesian government is aimed at enhancing efficiency, the effectiveness of state-owned enterprises (SOEs), as well as global competitiveness. The rationale in determining the demonopolization policy towards the two SOEs is based on the concept of neo-liberalism market economy, which promotes efficiency and effectiveness on free market competition. The concept of neo-liberal economics is contrary to the concept of democratic economics. The concept of democratic economics based on the 1945 Constitution of the Republic of Indonesia prioritizes fair efficiency. It is the reason for the Constitutional Court to return monopoly rights to PT. PLN (Persero) as an electricity provider in Indonesia. The argue of monopoly policy or demonopolization policy of SOEs is the main problem that will be elaborated through normative research methods (documentary research) by using secondary data as the main data. Problem analysis was done by qualitative juridical through of statute approach, philosophy approach, and history of law approach. This paper provides the reason of the policy of monopoly exemption on SOEs business activities, as well as the foundation of SOEs demonopolization policy taking into consideration the constitutional basis of Article 33 of the 1945 Constitution. The concept of demonopolization of SOEs is a new one that has never been described in the Indonesian literature. As a result, the demonopolization of SOEs does not divert SOEs into private companies but rather attempts to present competitors to SOEs to be able to compete in fair competition. In another side monopoly of SOEs can be implemented towards managing important production branches that control the livelihoods of many people. It is evidence of the state's role in ensuring the welfare of its people.
\end{abstract}

Keywords: Demonopolization; Indonesia; Monopoly; State-Owned Enterprises (SOEs).

\section{ARTICLE HISTORY:}

\section{DOI: 10.28946/slrev.Vol3.Iss2.126.pp124-136}

Received: Mar 25, 2018;

Reviewed: Jul 7, 2019;

Accepted: Jul 27, 2019;

Published: Jul 31, 2019.

* Faculty of Law, Universitas Sriwijaya, Indonesia.E-mail: putusamawati@fh.unsri.ac.id

\section{INTRODUCTION}

The establishment of state owned enterprises is a proof of state involvement in an economic activity, as a consequence of the development of the welfare state ${ }^{1}$, although the concept of the welfare state applied by the Indonesia government is the concept of the Pancasila welfare state, in which the involvement of the state or government is regarded as an obligation to organize and

1 Ibrahim, 2007, "Landasan Filosofis dan Yuridis Keberadaan BUMN: Sebuah Tinjauan”, Jurnal Hukum Bisnis, 26 (1), p8. 
direct society towards unity. ${ }^{2}$ The role of the state can be strengthened when it concerns the fulfillment of public services to its citizens and concerns the stability of state security, especially for sectors which is not capable to be undertaken by the private sector, and sectors involving important production branches and protecting the livelihood of whole society, then a government with a reason for the protection of public interest can make a monopolistic effort ${ }^{3}$ through the establishment of SOEs as stated in Article 51 of Law No. 5 of 1999 concerning Prohibition of Monopolistic practice and Unfair Business Competition and reinforced by the constitution of Article 33 of the 1945 Constitution of Indonesian paragraph (2) and (3).

The policy of a free-market-oriented economic system has an impact on Indonesia's economic policy. The monopoly of business activities involving important production branches and controlling the livelihood of the public by SOEs is being demobilized. The reason for the efficiency and effectiveness of SOE performance, which is always a loss ${ }^{4}$. The SOEs demonopolization policy is carried out on almost all state-owned enterprises, including state-owned power suppliers and state-owned port service providers. Basically, demonopolization is a government policy that provides opportunities for private

2 Philipus M. Hadjon, Perlindungan Hukum bagi Rakyat di Indonesia, Surabaya: Bina Ilmu, 1987, p77.

3 Holley H. Ulbrich, 1991, "Natural Monopoly In Principles", The Journal of Economic Education, 22 (2), pp179-182. Available from: www.jstor.org/stable/1182423, [retrieved: August 7, 2017].

4 Kwik Kian Gie, Praktek Bisnis dan Orientasi Ekonomi Indonesia, Jakarta: Gramedia Pustaka Utama \& IBBI, 1998, p32. companies to carry out business activities which have been monopolized by SOEs. In other words demonopolization relinquished the monopoly rights of SOEs in carrying out business activities, by presenting private companies as competitors. PT. PLN (Persero) as the state-owned power supply provider of Monopoly right is revoked based on the provisions of Article 9 paragraph (3) of Government Regulation No.14 of 2012 concerning Electricity Supply Business activity, although subsequently returned by Constitutional Court Decision No.111/ PUUXIII/2015. So it also happens to PT. Pelindo I-IV (Persero), which is a state owned enterprise of Port Service Provider, was originally authorized by PT. Pelindo (Persero) to conduct a monopoly in the regulation of the port sector in Indonesia with the enforcement of Law No.21 of 1992 concerning Shipping, and this monopoly right was revoked by the enforcement of Law No.17 of 2008 concerning Shipping, in particular in the explanation of Article 26 paragraph (1) stating that the regulation for the port field contains provisions on the abolition of monopoly in the implementation of ports.

Demonopolization of SOEs conducted by the government when associated with Article 51 of Law No. 5 of 1999 concerning Prohibition of Monopolistic Practices and Unfair Business Competition, is slightly different. Article 51 of Law No. 5 of 1999 provides support to SOEs to monopolize on the basis to protect the important production branches and protect the livelihood of the people. On the other side of the Government by issuing various regulations that demonopolize SOEs, especially state-owned enterprises that perform public service activities, as if asserted that the role of the 
state in protecting the welfare of the people began to be diverted to the private sector that is clearly more oriented to corporate profits and impossible to transfer it in the form provision of welfare guarantee of the people needed ${ }^{5}$.

The major problem of the enforcement of SOEs demonopolization by the government raises the assumption that there are no more important branches of production and concerns of the life of the people who need to get direct attention and management by the government, or even the economy based on fundamental norm of Indonesia (Pancasila) as mandated by Article 33 of the 1945 Constitution of Indonesia has a shift to economic liberalization. These allegations will be addressed by focusing on a discussion that lays out a rationale that provides a justification argument about demonopolization policy or simply restores monopoly policy to SOEs in conducting their business activities. The focus of the discussion will begin by describing the basic question of giving monopoly rights to SOEs in Indonesia based on Article 51 of Law No. 5 of 1999 concerning Prohibition of Monopolistic Practice and Unfair Business Competition. Furthermore, the paper will trace the rationale of revocation of monopoly rights to the SOEs Provider of Electric Power and SOE Port Service Provider by using the policy of demonopolization openly.

\section{METHODS}

Normative legal research or doctrinal research, was a research method used in answering various problems in this paper.

5 J. Stigler, "The Theory of Economic Regulation", in Teddy Anggoro, Monopoli Alamian BUMN, Depok: Herya Media, 2006, p153.
This normative study was conducted in an effort to try to answer the problem from the aspect of law principles and norms ${ }^{6}$. This means that the research was conducted to examine the positive law, in the sense of collecting, describing, systematizing, analyzing, interpreting and assessing positive legal norms that give the basic justification of justification between monopoly policy or demonopolization of business activities undertaken by SOEs ${ }^{7}$. This normative study also includes doctrinal research by finding legal rules that give arguments about monopoly policy by SOEs by taking into account the content of meaningful production branches which were important for the state affecting the livelihood of the people as a form of giving ideas about the ideal concept. On the other hand it also gives a thought on the basis of SOEs demonopolization policy aimed at efficiency and effectiveness of the performance of SOEs, and follow the demands of free market in international economic system for the improvement of state development progress.

The research approach used philosophical approach, statute approach, and legal history approach. The analysis was performed by the doctrinal method to determine how the legal subject should perform its obligations and obtain its rights. The results of normative-prescriptive analysis arrived at a conclusion as the exposure of thoughts on the justification to impose a monopoly or demonopolization of SOEs as a policy option that can be used by the government in an effort to create a fair

6 Soejono dan Abdurrahman, Metode Penelitian Hukum, Jakarta: Rineka Cipta, 2003, p112.

7 Bernard Arief Sidharta, Filsafat Ilmu Hukum. Bandung: Laboratorium Hukum Fakultas Hukum Universitas Khatolik Parahyangan, 2001, p23 
business competition market using qualitative descriptive analysis method ${ }^{8}$. The conclusion was done inductively by looking at special facts by taking a study on SOEs providers Power Services and SOEs port service providers, then would be obtained the concept of a general nature to be applied thoroughly ${ }^{9}$.

\section{ANALYSIS AND DISCUSSION Rationale for Granting Monopoly Rights to SOEs Providers of Electric Power Based on Law in Indonesia.}

Article 51 of Law No. 5 of 1999 Concerning the Prohibition of Monopolistic Practices and Unfair Competition, states that the monopoly and/or concentration of activities related to the production and/or marketing of goods or services affecting the livelihood of the people and the production branches that are important to the state shall be governed by law and organized by State-Owned Enterprises and/or public institutions established or appointed by the Government. Observing Article 51 of Law No.5 of 1999, it find a closely correlation with the 1945 Constitution of the Republic of Indonesia, especially paragraph (2), which formulates that the production branches that are important for the state and control the livelihood of the people are controlled by the state. Based on Article 33 Paragraph (2) of the Constitution 1945. There are 2 (two) points emphasized in the article, namely: ${ }^{10}$

1. The meaning of the production branches that are important for the state and affect

8 Noeng Muhadjir, Metodologi Penelitian Kualitatif, Yogyakarta: Rake Sarasin, 1998, p29.

9 Bambang Sunggono, Metodologi Penelitian Hukum, Jakarta: Raja Grafindo Persada, 2007, p10.

10 Rachmadi Usman, Hukum Persaingan Usaha di Indonesia, Jakarta: Sinar Grafika, 2013, pp175179. the livelihood of the people, this means the income of goods and services felt vital to human life in a certain period, while within the relevant time limited supply, so that suppliers can determine the price and terms-other trade conditions that harm the masses for their personal gain. In other words Production branches that control the livelihood of the people are divided into three categories, namely:

a) Related allocations, goods or services derived from natural resources.

b) Related to the distribution, the basic needs of society, but a time or continuously can not be met the market.

c) Related to stabilization such as defense of security, monetary, fiscal and regulation

2. The notion of "controlled by the state" which means mastery in a broad sense, which includes the notion of ownership in the public and civil sense, as well as the power in controlling and managing the fields of business directly by the government or government apparatus burdened with special duty.

Referring to the understanding of Article 33 of the 1945 Constitution of the Republic of Indonesia, it can be seen that the government has the duty of safeguarding the economy of the Indonesian state, especially in the case of the production factors which affect the livelihood of the people in order to be disbursed to the people and not monopolized by private parties. The dominance of important production branches for the state is intended to protect state assets in the form of natural resources and human resources. The importance of the position of 
the state as the ruler of the natural wealth of Indonesia, confirmed by Bung Hatta as an effort to ensure the benefits of natural wealth for the greatest prosperity of the people. $\mathrm{He}$ also stated that what is referred to as important production branches for the state include basic industries and mining, while the production branches that control the livelihood of the people are water, electricity, gas, sugar, cement, copra and vegetable oil. ${ }^{11}$

In line on Article 33 of the 1945 Constitution of Indonesia which is reinforces the government's role in providing protection for Indonesia's economic development, Law No.5 of 1999 concerning Prohibition of Monopolistic practice and Unfair Business Competition was also prepared for the following purposes: ${ }^{12}$

1. Maintaining the public interest and improving the efficiency of national economy as one effort to improve people's welfare;

2. To create a conducive business climate through fair business competition so as to ensure the certainty of equal business opportunity for big business entity, medium business entity, and small business entity;

3. Prevent monopolistic practice, and or unfair business competition caused by business entity; and

4. The creation of effectiveness and efficiency in business activities.

Based on the objective of the establishment of Law No. 5 of 1999 it can be

11 Revrisond Baswir, Manifesto Ekonomi Kerakyatan. Yogyakarta: Pustaka Pelajar, 2010, pp32-34

12 Johnny Ibrahim, Hukum Persaingan Usaha: Filosofis, Teori, dan Implikasi Penerapannya di Indonesia, Cetakan ketiga. Malang: Bayumedia Publishing, 2009, p217 seen that the government has come out with a Law of state administration in juridical economic activity, namely the regulation of anti-monopoly and unfair business competition related to the production and marketing of goods and or services. However, in matters affecting the livelihood of the people as well as the important production branches for the state as referred to in Article 33 of the Indonesia Constitution 1945 there is an exception to the state, that is, the state is allowed to monopolize, as regulated specifically in Article 51 of Law No. 5 of 1999.

The regulation of monopoly exclusion is done in an effort to safeguard the public interest and improve the efficiency of the national economy as one of the efforts to improve the people's welfare. It is further stated in Article 51 of Law No. 5 of 1999 that, in the case of a monopoly, the rights of state owned enterprises and/or public institutions established or appointed by the Government. In practice these monopolistic exclusions are generally in the form of stateowned enterprises. This is because SOEs is a private state enterprise with its main function as Agent of development. ${ }^{13}$ The special stateowned enterprise lies in its capital, in which the capital of the SOEs either entirely or partially directly obtains equity participation from the separated state assets. The affirmation of separated state assets is the separation of state assets from the State Budget (APBN : Anggaran Pendapatan dan Belanja Negara) to be used as state equity participation in SOEs, for subsequent development and management is no longer

13 Aminuddin Ilmar, Hak Menguasai Negara dalam Privatisasi BUMN, Jakarta: Kencana Prenada, 2012, p76 
based on the state budget system but on good corporate government principles. ${ }^{14}$

The importance of the role of the state in the economy through monopoly policy is because the state is obliged to meet the needs of its people, only the state has control over regulation formation. In the public interest framework, The regulatory regime performs the task of maximizing social welfare through proper pricing and entry policies. ${ }^{15}$ Regarding the business activities that should be monopolized by the state through SOEs is the type of infrastructure industry, network industry, and natural resource management industry. The role of SOEs in these industries becomes very important, as it relates to the protection of national interests and ensures the affordability of the majority people of Indonesia. ${ }^{16}$ On the basis of the matter is the position of monopoly in the case of the implementation of electricity by PT. PLN (Persero) is returned based on the Decision of the Constitutional Court of the Republic of Indonesia No.111/PUU-XIII/2015. The decision of the Constitutional Court restores the right to administer electricity to the state conducted by SOEs, in other words the demonopolization policy as stipulated under Article 11 paragraph (1) of Law No. 30 of 2009 concerning Electricity and Article 9 paragraph (3) Government Regulation No. 14 of 2012 concerning Electricity Supply Business activities is contradictory to the provisions of state controls contained in

14 Rahayu Hartini, BUMN Persero: Konsep Keuangan Negara dan Hukum Kepailitan di Indonesia, Malang: Setara Press, 2017, p63

15 Sanford V. Berg, and John Tschirhart, Natural Monopoly Regulation: Principles and practice, Cambridge: Cambridge University Press, 2008, p285.

16 Teddy Anggoro, Monopoli Alamiah Badan Usaha Milik Negara, Depok: Herya Media, 2016, pp178179.
Article 33 paragraph (2) and (3) of the 1945 Constitution of Indonesia. ${ }^{17}$

In the Decision of the Constitutional Court of the Republic of Indonesia No.111/ PUU-XIII/2015, it is affirmed that electric power is an important production branch for the state and concerning the livelihood of the people, it is one of the primary needs for nation-development as all aspects of life require electricity. On the basis of Article 33 Paragraph (2) of the Indonesia Constitution 1945 , electricity must be controlled by the state, in the sense that it must be managed by the state through state-funded enterprises (state) or by a joint national or foreign private partnership that includes internal and external investor or by engaging private/ domestic capital with a good and mutually beneficial partnership system. This means that only SOEs are allowed to manage electric power businesses, while national or foreign private companies only participate if they are invited to cooperate by SOEs, whether with partnership, equity participation, capital loan, and others.

Electricity management conducted by PT. PLN (Persero) according to the Constitutional Court must be done entirely from generating, transmitting, and distributing power. The Constitutional Court is of the opinion that the production branch contained in Article 33 Paragraph (2) of the 1945 Constitution of Indonesia in the field of electricity should be interpreted as a unity between power generation, transmission and distribution. This is related to Article 33 Paragraph (4) of the 1945 Constitution of

17 Decision of the Constitutional Court of the Republic of Indonesia No. 111/PUU-XIII/2015 concerning The Verdict of the Judicial Review Law No. 30 of 2009 concerning The Electrification of the 1945 Constitutional of Indonesian. 
Indonesia which states that the national economy is organized based on economic democracy with the principle of togetherness, efficiency of justice, sustainability, environmental insight, independence, and by maintaining a balance between progress and unity of national economy. The word fair efficiency should be major concern. The reason for demonopolization against PT. PLN (Persero) because of efficiency following the market movement. Efficiency is the result of a competition, but it can have an impact on injustice, so economic democracy juxtaposes fair efficiency. This argument is contrary to the will of the Electricity Law. The Electricity Law embraces the concept of a market economy of neo-liberalism, which believes that economic elements must be left entirely to market mechanisms based on supply and demand. According to this concept, efficiency in electricity business can be generated from free market competition, but it will impact on unfair efficiency and does not reflect the spirit of economic democracy as referred to in Article 33 paragraph (4) of the 1945 Constitution of Indonesia. The opinion that confirms that electricity is included in important production branch and related to the livelihood of the people resulted in the return of monopoly status to PT. PLN (Persero) in the management of electric power in Indonesia.

\section{Rationale for Revocation of Monopoly Rights to SOEs Providers of Port Services by Enforce Policy of Demonopolization Openly.}

The principle of SOEs demonopolization conducted by the government aims to improve the efficiency and productivity of SOEs, by reducing the role of the state in the economic field. The basic aim of demonopolization is to create transparency, to gain access to international markets to facilitate the flow of funds, as well as for the transfer of knowledge. The function of demonopolization is divided into: ${ }^{18}$

a) The function of the corporation, is a major function of demonopolization because its implementation aims to form a state-owned enterprise into a tough corporation in global economic competition.

b) The function of competition, is a function that emphasizes the ability to compete from SOEs in the face of competitors in business sectors similar to business ventures.

c) The function of regulation, is a function performed by the existing government authorities in organizing a variety of policies and strict regulations in the economic sector, so as to increase the competitive pro to the market.

d) Budget function, intended implementation of demonopolization of the government can increase the state treasury to development the public interest.

Demonopolization is an attempt to abolish the monopoly, ${ }^{19}$ in other words a situation in which a business entity is granted the right to monopolize a particular business activity, then that right is revoked by applicable laws or regulations. 20

18 Safri Nugraha, 2007, "Privatisasi BUMN: Antara Harapan dan Kenyataan," Jurnal Hukum Bisnis, 26 (1), p16

19 Kamus Besar Bahasa Indonesia online. Available from: http://kbbi.web.id/ demonopolisasi.html

20 Petersen, Niels, 2013, "Antitrust Law and The Promotion of Democracy and Economic Growth", Journal of Competition Law \& Economic, 9 (3). 
Demonopolization has a notion that different from privatization. Privatization is a process of distribution of ownership transfers that were formerly controlled and administered by the state then transferred to the private sector, the transition not only in the form of asset SOEs (stock) shares but also the service contract that was formerly carried out by the state to private investor. ${ }^{21}$ The termed Privatization in Indonesia is "privatization", in other words the status of SOEs which is owned fully by state becomes private or partowned entirely. Some literature is equated between demonopolization and privatization as done by Dewatripont and Roland in their article in Economic Journal of the University of Parto Year 1992 entitled "The Virtues of Gradualism and Legitimacy in The Transition to Market Economic". The statement was denied by Artur Rodriques and Paulo J Pereira ${ }^{22}$ who comes from the same university, that demonopolization is in fact more general and broader, it is a condition in which a business activity originally monopolized by a state enterprise is subsequently released, the disposal of such monopoly can be privatized or by establishing competitor companies. A similar

Doi:10.1093/joclec/nht003. available from http://jcle.oxfordjournals.org/at Gadjah Mada University. [retrieved: November 9, 2015], p603

Jay G. Martin, 1999, "An Overview of The Privatization of The Latin American Oil and Gas Sector”. Rocky Mountain Mineral Law Special Institute 103A RMMLF-INST9, Available from: http://www.jstor.org/stable/40924393. [retrieved: September 4, 2016]

21 Ewa Baginska, 1995, "Privatization Proses in Poland: Legal Aspect of The Privatization Process in Poland," Thesis in Nicolaus Copernicus University: Poland, p1

22 Artur Rodriques and Paulo J Pereira, 2011, "Investment Decisions in Granted Monopolies Under The Threat of a Random Demonopolization," Economic Jornal Faculty of Economic University of Parto, Portugal, p2 statement is also expressed by Liuben Berov, that privatization is one of the forms/types of demonopolization of state enterprises. ${ }^{23}$

Demonopolization also opens opportunities for private companies to compete in similar business activities with state enterprises, and the primary objective of providing consumers with choice to obtain better quality products (goods/ services). ${ }^{24}$ The fundamental point of the demonopolization exercise should be to create a pluralist entrepreneur in the conduct of a similar business, in other words the business owned should not be sole, and demonopolization must be done through legislation. ${ }^{25}$ Demonopolization is one strategies that can be undertaken to improve competitiveness for state enterprises that are considered less productive as a result of less professional management. The proposed demonopolization in this case is a form of demonopolization by allowing the private sector to establish a competitor company for a state enterprise, not in the form of privatization of a state enterprise. If the government opens opportunities for the private sector to conduct business activities similar to the business activities of stateowned companies that have been

23 Liuben Berov, 1993, "Demonopolization and International Competition in Bulgaria 1990-1991." Russian and Eastern European Finance and Trade Journal. 29 (1) Taylor \&Francis Ltd.: Russian. Available from:http://www.jstor. org/stable/27748962, [retrieved: July 7, 2017], p89.

24 Mikulas Sedlak and Ivanka Roberts, 1991, “An Inevitable part of Economic Reform: Demonopolization and The Development of Economic Competition," Soviet and Eastern European Foreign Trade Journal, 27 (2), Taylor \& Francis Ltd: Soviet, Available from: http://www.jstor.org/stable/2774925, [retrieved: January 8, 2018], p55.

25 Ibid, p56. 
monopolized, with the guarantee of fair business competition then the impact will be to improve consumer life. According to Thomas S. Friedland, there are at least five effects of the enforcement of demonopolization by the government, namely: ${ }^{26}$

1. At the transition of profits, the consumer initially has no choice of a product because it is monopolized, product (goods / services) choices become more diverse.

2. Product price is cheaper.

3. Competitive quality and price of products.

4. Increased revenues/income for entrepreneurs due to open access to business.

5. Increased revenue for the government, from opening employment opportunities, tax revenues, and other possible revenues.

The study of the concept of demonopolization has not been discussed specifically in the literature or in the form of articles in Indonesia. Demonopolization in the form of giving equal opportunity to the private sector to be a competitor of SOEs who have been doing business in a monopoly will provide a discourse of thought to be regulated further as well as the privatization that has been established legislation.

In logic of the state, monopoly is indeed the authority of the state in order to guarantee the welfare of its people. But to be underlined is the monopoly policy should not

26 Thomas S. Friedland, 1978, "The Estimation of Welfare Gains From Demonopolization," Southern Economic Journal, 45 (1), Southern Economic Association: USA, Available from: http://www.jstor.org/stable/1057620, [retrieved: May 10, 2017], p117. hinder efforts to meet people's needs. It can be not let the noble cause for the welfare of the people actually turned into inconvenient people and even misery of the people. ${ }^{27}$ Demonopoly policy was taken by the government because a reason to revitalize the SOEs that had often experienced losses. According to Bacelius Ruru, basically revitalization of SOEs can be done through two ways of improving SOEs both externally and internally. Settlement can be done one of them by giving more opportunities to the private sector into the market, thus battling SOEs and ultimately can motivate SOEs to grow up/increase. ${ }^{28}$ One of the objectives of the establishment of SOEs is to seek profit from its business activities, but the performance of SOEs is not merely for profit, but it must pay attention to the public interest. This is because the business entity is majority or all of its capital is owned by the state. The government as a representative of the state has an obligation to carry out the duties of the state, among them is the conduct of public service. Providing public services to prioritize public interests is a privilege of SOEs that are not owned by private companies. This is behind the reason to improve the performance of SOEs by presenting competitors who are engaged in the same business.

The option of demonopolization is considered better than privatization, because demonopolization still gives the status of the company to a state enterprise whose business orientation is not only for profit but also

27 Nusantara ed. all, Litigasi Persaingan Usaha: Competition Litigation, Tangerang: Telaga Ilmu Indonesia, 2010, p63

28 Bacelius Ruru. "Arah Kebijakan BUMN menghadapi Era AFTA 2003 dan APEC 2020". Jurnal Keuangan dan Moneter. Jakarta. Volume 3 Nomor 1. April 1996, pp8-9. 
public service. One of the demobilized companies is PT. Pelindo (Persero). The provision of port services in Indonesia is carried out by State Companies since the 1960s conducted in a monopoly manner. Originally the form of State Enterprise is a Public Company (in Indonesia call by Perusahaan Umum), then in 1992 changed to Private Company (in Indonesia call by Persero). The main characteristic of Persero is the pursuit of profit in order to increase the value/Good Name of the company. ${ }^{29}$ Unlike Private Company (Persero), the main characteristic of Public Company (Perum) is to provide services and public benefits. ${ }^{30}$ State-owned enterprises in the form of Persero are expected to provide a high income for the state from the results of its business activities through dividends for the government as shareholders. The desire to continuously improve the performance of PT. Pelindo (Persero) conducted by the government by enacting the demonopolization policy through the enforcement of Law No. 17 Year 2008 concerning Shipping. Article 26 paragraph (1) states that the regulation for the port field contains provisions concerning the abolition of monopoly in the implementation of ports.

Currently, the port services operators in Indonesia are not only conducted by the government, but it has been possible for the private sector to participate. Since the enforcement of Law No.17 of 2008 concerning Shipping, it is mandatory that any company that will undertake port service provision and port services on a

29 Article 12 Law No. 19 of 2003 concerning States Owned Enterprises. State Register No. 70. Additional State Register No. 4297

30 I G Rai Widjaya, Hukum Perusahaan: Berbagai Peraturan Pelaksanaan Undang-undang di Bidang Usaha, Jakarta: Kesiant Blanc, 2000, pp75-76 commercially port shall be licensed as a Port Business Entity (PBE) granted by the Minister of Communications for major and non-collectors, by the Governor for regional feeder ports, and by the Mayor/Regent for local feeder ports. PBE consists of SOEs, Regional Owned Enterprises (ROEs), and private. PBE Laws as an operator that manages and operates on one or more port terminals and facilities. PBE may undertake port supply and/or service activities which include the provision and/or service of ships, goods and passengers. The type of supply and/or port services provided can be: ${ }^{31}$

1. Docking services for tethering;

2. Fueling and fresh water services;

3. Up and down facilities of passengers and vehicles;

4. Docking services for loading and unloading of goods and containers;

5. Warehouse and stockpiling, loading and unloading equipment, and port equipment;

6. Coal terminals, liquid bulk, dry bulk, and Roll on-Roll off;

7. Cargo loading and unloading of goods;

8. Vessel suspension service.

Seeing the diversity of activities from the provision and/or port services and supporting ports, certainly provides opportunities for the private sector to enter the same business activities with SOEs. The thing that needs to be paid attention is about the fair competition system and the government's alignment towards the middle and lower enterprises and cooperatives that must be protected.

Determination of the implementation of monopoly policies or demonopolization of

31 http://www.indonesiaport.co.id/sub/produk-and-
layanan.html 
SOEs in Indonesia is put on two main variables, namely:

1. Is the existence of the SOEs running business activities related to important production branches for the state; and

2. Does the existence of the SOEs running business activities that concern the lives of many people.

The main thing is that the demonopolization policy of SOEs is not interpreted as an attempt by the government to be irresponsible in ensuring the fulfillment of the needs of its people. Demonstropolization of SOEs is carried out in an effort to increase the competitiveness of SOEs to be able to become an international corporation. The presence of private companies as competitors of SOEs will also increase investment and increase state revenues which indirectly will increase the stability of Indonesia's economic development. The existence of SOEs will also be the controller of market prices that can guarantee the affordability of the community in fulfilling their daily needs. An important point that must also be taken into consideration by the government in enacting a demonopolization policy on SOEs is followed by a policy of improving the quality of human resources that will manage SOEs to be able to compete with private companies

\section{CONCLUSION}

PT. PLN (Persero) is a state company conducting business activities in the field of electricity supply originally granted the right of monopoly through Law No.15 of 1985 concerning electricity. Then the government enacted the demonopolization policy of PT. PLN (Persero) pursuant to Article 11 paragraph (1) of Law No. 30 of 2009 and Article 9 paragraph (3) of Government Regulation No. 14 of 2012 concerning
Electricity Supply Business activities, although subsequently returned by Constitutional Court of Indonesia Republic decision No.111/PUU-XIII/2015. The Constitutional Court of Indonesia Republic said electricity is a major needed for Indonesia people. Besides that, our economic system is economic democracy which is base on fair efficiency. Electricity is one of the major branch of important production for Indonesia government. It is also control the livelihood of the Indonesia people.

PT. Pelindo (Persero) is a State Owned Enterprises which is give port services operators. It's one of SOEs that effect of demonopolization policy. Demonopolization policy to PT. Pelindo (Persero) is an implementation of Article 26 paragraph (1) Law No.17 of 2008 concerning Shipping. As a SOEs, PT. Pelindo (Persero) must be competed among private company. Efficiency and effectiveness are a reason for make over PT. Pelindo (persero) in order to be international company. Demonopolization policy opens opportunities for private company to built a similar business activities. Government have purpose that economic growth will be increase and people as a consumers could be take advantage from government policy. The Implication of the de-monopolization policy of SOEs is the ability of SOEs to be able to have competitiveness and be able to provide affordable products for many people. Equally important is to separate the role of regulators, controllers, and supervisors to the government, and the role of providers of services/goods for the public to business entities. It will make SOEs professionally managed and able to fulfill their founding goals as an agent of development. 


\section{REFERENCES}

Anggoro, Teddy. 2016. Monopoli Alamian $B U M N$. Depok: Herya Media.

Baswir, Revrisond. 2010. Manifesto Ekonomi Kerakyatan. Yogyakarta: Pustaka Pelajar.

Berg, Sanford V., John Tschirhart. 2008. Natural Monopoly Regulation: Principles and PrLawice. Cambridge: Cambridge University Press.

Gie, Kwik Kian. 1998. Praktek Bisnis dan Orientasi Ekonomi Indonesia. Jakarta: Gramedia Pustaka Utama \& IBBI.

Ilmar, Aminuddin. 2012. Hak Menguasai Negara dalam Privatisasi BUMN. Jakarta: Kencana Pranada.

Hadjon, Philipus M. 1987. Perlindungan Hukum bagi Rakyat di Indonesia. Surabaya: Bina Ilmu.

Hartini, Rahayu. 2017. BUMN Persero: Konsep Keuangan Negara dan Hukum Kepailitan di Indonesia. Malang: Setara Press.

Ibrahim, Johnny. 2009. Hukum Persaingan Usaha: Filosofis, Teori, dan Implikasi Penerapannya di Indonesia. Cetakan ketiga. Malang: Bayumedia Publishing.

Muhadjir, Noeng. 1998. Metodologi Penelitian Kualitatif. Yogyakarta: Rake Sarasin.

Nusantara, Abdul Hakim., Erman Rajagukguk, HMBC Rikrik Rizkiyana, dan Vovo Iswanto. 2010. Litigasi Persaingan Usaha: Competition Litigation. Tangerang: Telaga Ilmu Indonesia.

Bacelius Ruru. "Arah Kebijakan BUMN menghadapi Era AFTA 2003 dan APEC 2020". Jurnal Keuangan dan Moneter. Jakarta. Volume 3 Nomor 1. April 1996.
Sidharta, Bernard Arief. 2001. Filsafat Ilmu Hukum. Bandung: Laboratorium Hukum Fakultas Hukum Universitas Khatolik Parahyangan.

Soejono dan Abdurrahman. 2003. Metode penelitian hukum. Jakarta: Rineka Cipta.

Sunggono, Bambang. 2007. Metodologi Penelitian Hukum. Jakarta: Raja Grafindo Persada.

Usman, Rachmadi. 2013. Hukum Persaingan Usaha di Indonesia. Jakarta: Sinar Grafika.

Widjaya, I.G.Rai. 2000. Hukum Perusahaan: Berbagai Peraturan Pelaksanaan Undangundang di Bidang Usaha. Jakarta: Kesiant Blanc.

\section{Journal and Legislation}

Decision of the Constitutional Court of the Republic of Indonesia No. 111/PUUXIII/2015 concerning The Verdict of the Judicial Review Law No. 30 of 2009 concerning The Electrification of the 1945 Constitutional of Indonesian.

Baginska, Ewa. 1995. "Privatization Proses in Poland: Legal Aspect of The Privatization Process in Poland", Makalah, Nicolaus Copernicus University: Poland.

Berov, Liuben. 1993. "Demonopolization and International Competition in Bulgaria 1990-1991". Russian and Eastern European Finance and Trade Journal. 29 (1) Spring, 1993. Available from: http://www.jstor.org/ stable/27748962. [retrieved: July 7, 2017]

Friedland, Thomas S. 1978. "The Estimation of Welfare Gains From Demonopolization". Southern Economic Journal. 45 (1) July 1978. Southern Economic Association: USA. Available from: http://www.jstor.org/ stable/1057620. [retrieved: May 10, 2017]

Ibrahim. 2007. "Landasan Filosofis dan Yuridis Keberadaan BUMN: Sebuah Tinjauan". Jurnal Hukum Bisnis 26 (1). 
Martin, Jay G. 1999. "An Overview of The Privatization of The Latin American Oil and Gas Sector". Natural Resources \& Environment Journal, 14(2). Available from: http://www.jstor.org/stable/40924393. [retrieved: September 4, 2016].

Martinez, Elizabeth and Garcia, Arnoldo. 1997. "Neoliberalism: A Brief Definition for Lawivities". National Network for Imigrant and Refugee Right. Available from: http://www.nnirr.org/drupal/. [retrieved: April 12, 2017]

Nugraha, Safri. 2007. "Privatisasi BUMN: Antara Harapan dan Kenyataan". Jurnal Hukum Bisnis. 26 (1).

Petersen, Niels. 2013. "Antitrust Law and The Promotion of Democracy and Economic Growth". Journal of Competition Law \& Economic. 9(3). Doi:10.1093/joclec/nht003. Available from: http://jcle.oxfordjournals.org/ [retrieved: November 9, 2015]
Rodriques, Artur. and Pereira, Paulo J. 2011. "Investment Decisions in Granted Monopolies Under The Threat of a Random Demonopolization." Economic Journal Faculty of Economic University of Parto: Portugal. [retrieved: September 4, 2016]

Sedlak, Mikulas and Roberts, Ivanka. 1991. "An Inevitable part of Economic Reform: Demonopolization and The Development of Economic Competition". Soviet and Eastern European Foreign Trade Journal. 27 (2) Taylor \& Francis Ltd: Soviet. Available from: http://www.jstor.org/ stable/2774925. [retrieved: January 8, 2018]

Ulbrich, Holley H. 1991. "Natural Monopoly In Principles". The Journal of Economic Education. 22 (2). Available from: http:// www.jstor.org/stable/1182423. [retrieved: August 7, 2017]. 